Communication

\title{
Rivers and Wastewater-Treatment Plants as Microplastic Pathways to Eastern Mediterranean Waters: First Records for the Aegean Sea, Greece
}

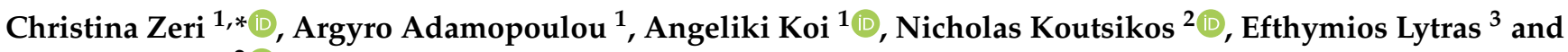 \\ Elias Dimitriou $^{2}$ (D) \\ 1 Institute of Oceanography, Hellenic Centre for Marine Research, 19013 Anavyssos, Greece; \\ adamopoulou@hcmr.gr (A.A.); angelikimariakoi@yahoo.com (A.K.) \\ 2 Institute of Marine Biological Resources and Inland Waters, Hellenic Centre for Marine Research, \\ 19013 Anavyssos, Greece; nkoutsik@hcmr.gr (N.K.); elias@hcmr.gr (E.D.) \\ 3 Athens Water and Sewerage Company S. A. (E.Y.D.A.P.), Research and Development, 11146 Athens, Greece; \\ lytras@eydap.gr \\ * Correspondence: chris@hcmr.gr
}

check for updates

Citation: Zeri, C.; Adamopoulou, A.; Koi, A.; Koutsikos, N.; Lytras, E.; Dimitriou, E. Rivers and

Wastewater-Treatment Plants as Microplastic Pathways to Eastern Mediterranean Waters: First Records for the Aegean Sea, Greece. Sustainability 2021, 13, 5328. https://doi.org/10.3390/su13105328

Academic Editor: Changhyun Roh

Received: 20 April 2021

Accepted: 6 May 2021

Published: 11 May 2021

Publisher's Note: MDPI stays neutral with regard to jurisdictional claims in published maps and institutional affiliations.

Copyright: (c) 2021 by the authors. Licensee MDPI, Basel, Switzerland. This article is an open access article distributed under the terms and conditions of the Creative Commons Attribution (CC BY) license (https:/ / creativecommons.org/licenses/by/ $4.0 /)$.

\begin{abstract}
The present work provides the first records on microplastic (MP) amounts and types in rivers and wastewater effluents entering the Aegean Sea, eastern Mediterranean. Two rivers were sampled using a manta net (mesh size, $0.33 \mathrm{~mm}$ ): a small urban and a medium-sized river with a rural, semiurban catchment. MPs in wastewater samples were collected at two wastewater treatment plants (WWTPs) within the Athens metropolitan area after secondary treatment and from a pilot biological membrane unit (MBR), using a series of sieves. MPs in the samples were identified using stereoscopic image analysis and spectroscopic techniques. MP concentrations in the rivers were found to be variable, with as high as 27.73 items $\mathrm{m}^{-3}$ in the urban river. Differences in MP shape types, sizes, and polymer types reflect catchment size and usage. MP concentration in wastewater effluents was found to be 100 times higher in the secondary treatment $\left(213\right.$ items $\left.\mathrm{m}^{-3}\right)$ than that in the pilot MBR (2.29 items $\mathrm{m}^{-3}$ ), with filaments and polymers indicative of synthetic textiles and household use. Further research is needed in order to accurately determine variability in MP concentrations and fluxes from these two pathways in the eastern Mediterranean Sea and elucidate the role of rivers in MP retention.
\end{abstract}

Keywords: freshwater; pollution; sewage; FT-IR; WWTP; pilot MBR

\section{Introduction}

Plastics are manufactured petroleum-based polymers used in all kinds of consumer products, from single-use items and packaging to automobile parts. Their extensive use during the last few decades has led to an exponential increase in the generation of plastic waste, and the subsequent mismanagement and dispersion of plastics in the environment. Plastic pollution is widely recognized as a global problem of ecological significance. Plastics are recorded in all environmental compartments, spanning from highly populated areas to remote regions [1]. The environmental concerns of this kind of pollution lie mostly on the chemical persistence of plastics and their fragmentation to small particles $(<5 \mathrm{~mm}$ ) called microplastics (MPs) under environmental conditions (photodegradation, hydrolysis, physical weathering) [2-4]. On the basis of their mode of formation, MPs can be categorized into two types: primary and secondary. Primary MPs are considered to be small manufactured plastic particles intentionally added as constituents in various cleansing products (toothpaste, facial scrubs, detergents, etc.), and industrial plastic pellets that are the raw materials of the plastic industry. Secondary MPs are those produced during the use of materials and products such as car tires, paints, and synthetic clothes during their life cycle or from the fragmentation of plastic waste in the environment 
after the end of a product life cycle. All these types of MPs, originating from various land sources, ultimately find their way to marine environments through runoff, river transport, or wastewater discharge [5]. Research on microplastics in marine environments provides information on their distribution and circulation modes [6-8], their role in the transfer of chemicals via adsorption and desorption mechanisms [9-11], interactions and impact on marine biota through ingestion or colonization [12-14], and, more recently, on their effects on natural-ecosystem functioning [15-17]. Nonetheless, there is relatively little information on the amounts and types of MPs entering marine environments from land. Global estimates on plastics fluxes from rivers into the oceans range from 0.8 to 2.7 million tons per year, indicating the importance of this pathway [18-20]. For MPs in particular, studies showed that rivers, especially urban rivers, carry considerable amounts of MPs, with concentrations 40-50 times higher than the maximal concentration recorded on the surface of the oceans [19]. Works on WWTPs, on the other hand, showed that, depending on the degree of treatment, about $80-95 \%$ of MPs found in sewage are trapped in sludge [21,22]. However, WWTPs still serve as microplastic pathways to aquatic environments due to the high amounts of effluent discharge, especially from large cities and highly urbanized areas. On the basis of concentrations of MPs floating on the surface waters, the Mediterranean Sea is considered to be a hot-spot area that is comparable to oceanic accumulation zones [23-25]. Nevertheless, information on the role of Mediterranean rivers [26,27] and WWTPs [28-31] in the transport of MPs is still limited.

The present work contributes to filling this knowledge gap by providing the first records on MP amounts and types in waters entering the Aegean Sea (eastern Mediterranean Sea) from two different types of small rivers (an urban and a rural one), and from treated sewage effluents. The various sources of MPs are discussed on the basis of their shape properties, polymer identity, and the relative importance of the two pathways.

\section{Materials and Methods}

\subsection{Study Sites}

\subsubsection{Rivers}

Two rivers outflowing in the Aegean Sea were studied (Figure 1). The Kifissos Attica River, a small urban river, drains in the catchment of the western part of Athens metropolitan area ( $\sim 3.8$ million inhabitants). The river is $\sim 25 \mathrm{~km}$ long, flows along the west part of the city and ends up in the Saronikos Gulf close to the port of Piraeus. For most of the year, water flow is low $\left(3.2 \mathrm{~m}^{3} \mathrm{~s}^{-1}\right)$ [32], but the river is subject to flooding events depending mainly on annual precipitation, during which water fluxes may reach from 700 to $1400 \mathrm{~m}^{3} \mathrm{~s}^{-1}$ [33]. Approximately $70 \%$ of its catchment is currently a built-up urban area characterized by mixed land uses, such as operating and abandoned factories, small and medium-sized enterprises, warehouses, and illegal areas for the fly tipping of solid waste. The main highway runs along the river basin, and the last $10 \mathrm{~km}$ of the river corridor are channeled under the highway. All these activities led to the chemical pollution of the river water and sediments [34,35]. The Pinios Thessaly River basin is located in central Greece, one of the most intensely cultivated agricultural areas, and flows out into the Aegean Sea (Figure 1). The Pinios hydrological basin is approximately $9800 \mathrm{~km}^{2}$ with an average discharge of $103 \mathrm{~m}^{3} \mathrm{~s}^{-1}$ [36]. Apart from intensive agricultural activities that led to the extensive use of agrochemicals, groundwater overexploitation, deforestation, and heavy soil erosion, the Pinios River also faces significant threats from semi-industrial activities (e.g., olive mills and slaughterhouses) and hydromorphological alterations (e.g., dams and channelization) [36]. In addition, treated waste from the cities of Larissa ( 150,000 inhabitants) and Trikala ( 60,000 inhabitants) flows out into the river. Both are considered to be typical small-to-medium-sized Mediterranean river types (with seasonal high and low hydrological regimes) that discharge into the Aegean Sea, and area important freshwater contributors of organic matter from central and southern Greece to eastern Mediterranean waters. On the basis of all the above, our study contributes to the identification of MP river pathways and their relative importance, since they cover different features, and 
display several and diverse stressors from various sources, further affecting the eastern Mediterranean basin.

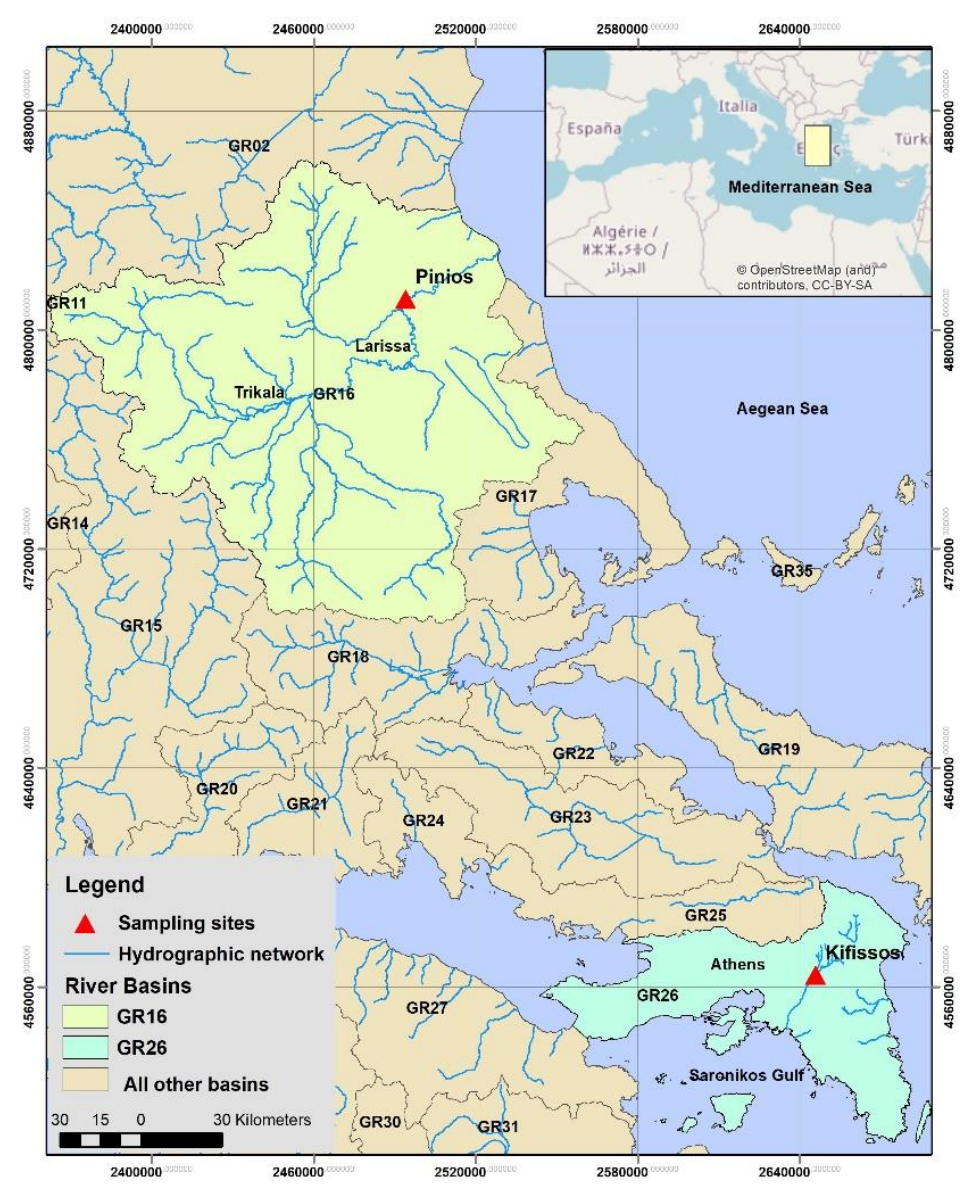

Figure 1. Map of two rivers (Kifissos and Pinios) flowing out into the Aegean Sea, eastern Mediterranean. Sampling sites also shown.

\subsubsection{Wastewater-Treatment Plants}

Wastewater from two plants operating in the periphery of the city of Athens was studied for MP presence. The first plant, WWTP1 (EL300102015; http: / astikalimata.ypeka. $\mathrm{gr} /$, accessed on 17 January 2021), is situated at a rural area west of Athens and receives the effluents of a small city $(\sim 30,000$ inhabitants) that are subject to secondary treatment. The treated effluents of $\sim 1870 \mathrm{~m}^{3} \mathrm{~d}^{-1}$ (annual mean) are then transported to the Saronikos Gulf. The second plant, WWTP2 (EL300026013; http:/ / astikalimata.ypeka.gr/, accessed on 17 January 2021), is situated northwest of the city of Athens and receives the sewage of the northern suburbs $(\sim 60,000$ inhabitants), a purely residential area, and all sewage originating from septic tanks (cesspits; 187,000 inhabitants). At this plant, the R\&D department of the company operates a pilot sewer mining unit with a membrane bioreactor (MBR), the effluents of which were sampled for the present study. Sewer mining is the process of tapping into a wastewater system and extracting wastewater that is then treated and used as recycled water. Feedwater was pumped from the local sewerage network to the sewer mining unit, where it passes through a preliminary treatment that includes a coarse screen with $20 \mathrm{~mm}$ openings and a compact fine screen-grit system. The screens with an opening of $6 \mathrm{~mm}$ allow for the retention of solids and the grit-grease unit for the protection of downstream equipment from sand particles, grease, and oil. Outlet flow from the pretreatment unit enters the equalization tank, from where sewage is pumped to the main treatment units. The main treatment units consist of a fine $1 \mathrm{~mm}$ screen and biological treatment with MBR (0.03 $\mathrm{mm}$ membrane pore opening). 


\subsection{Sampling}

Our sampling site at Kifissos River was $~ 12 \mathrm{~km}$ downstream $(23.768$ E, $38.079 \mathrm{~N})$, after the river enters the part with mixed land uses. The river water was sampled twice, on 6 December 2018 and 10 July 2019, during high and low river flow, respectively (Figure 2a). At Pinios River, water was sampled downstream (22.405 E, $39.812 \mathrm{~N})$, after the city of Larissa, on 11 June 2019 (Figure 2b). Two replicate samples were collected. River-water flux during the days of our samplings was measured with a flow meter (Global Water FP101). Sample collection in both rivers was conducted using a manta net with a $330 \mu \mathrm{m}$ mesh size. The net was kept still in the middle of the river basin for $25 \mathrm{~min}$ by fastening its sides with ropes at the banks (Figure 2). The volume of the sampled water was calculated on the basis of the river flux, the geometry of the net's mouth, and the duration of each sampling. The cod end was then transported to the laboratory for MP separation and analysis.

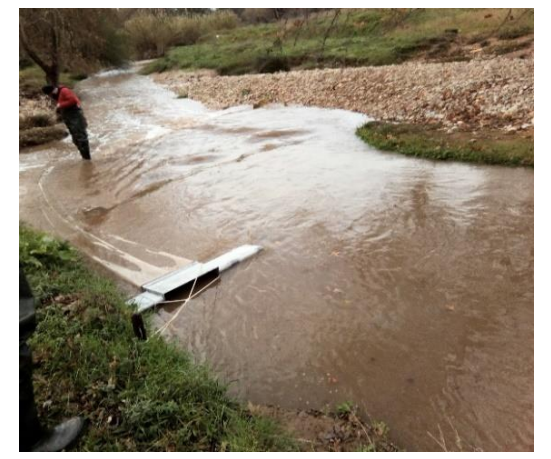

(a)

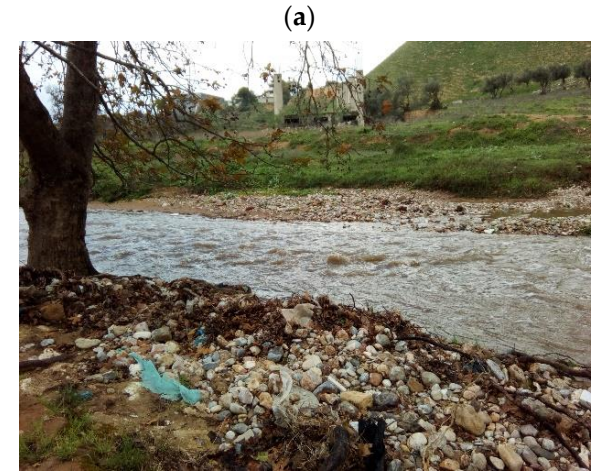

(c)

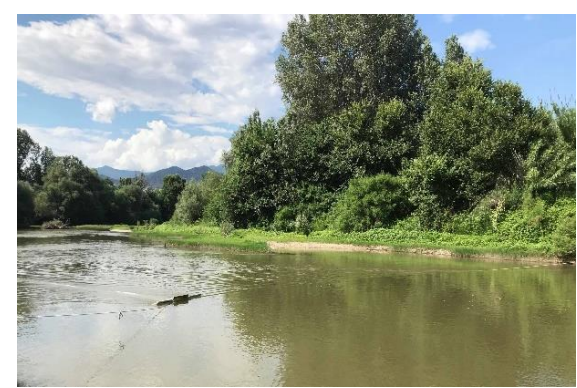

(b)

Figure 2. Microplastic sampling with manta net in (a) Kifissos River and (b) Pinios River. (c) Plastic sheets and bags thrown along the banks of Kifissos River.

At WWTP1, a volume of $0.0025 \mathrm{~m}^{3}$ influent was collected as an instantaneous sample on 4 December 2018 and on 28 March 2019. During the same dates, $\sim 1 \mathrm{~m}^{3}$ of treated effluents after secondary sedimentation and before the chlorination step was pumped using a submersible pump and filtered for MP detection. At WWTP2, we sampled the incoming sewage and the final effluent from the pilot sewer mining unit. The equalization tank was intermittently filled with the influent for approximately 7 days from 5 to 11 June 2019. On 11 June 2019, a volume of $2.5 \mathrm{~L}$ was collected and considered to be a composite influent sample. This was repeated from 12 to 20 June 2019, when a second influent sample was collected. The effluent from the pilot sewer mining unit (MBR permeate) was sampled for MP presence. During each period, $12 \mathrm{~m}^{3}$ of MBR permeate was filtered for MP detection. All wastewater samples were filtered through a stack of inox filters with $0.3,0.2$, and $0.1 \mathrm{~mm}$ mesh sizes using a filtration device specifically designed for this purpose [37].

\subsection{Microplastic Separation and Counting}

Sample processing for MP counting and characterization was conducted following the guidelines described in [38]. Material collected in the manta-net samples from the 
rivers was transferred into preweighed glass beakers with as low water content as possible and dried in an oven at $40{ }^{\circ} \mathrm{C}$ for $24 \mathrm{~h}$. The same treatment was applied to the filtered samples from WWTPs. For the removal of organic matter that was present in all samples, $40 \mathrm{~mL}$ of $15 \%$ hydrogen peroxide $\left(\mathrm{H}_{2} \mathrm{O}_{2}\right)$ per $3 \mathrm{gr}$ of dry sample was added and heated on a hot plate (approx. $40{ }^{\circ} \mathrm{C}$ ) until digestion was complete, approximately $24 \mathrm{~h}$. Then, the digests were collected with D.I. water and filtered through GF/C filters $(\sim 1.2 \mu \mathrm{m}$ particle retention). MP detection was conducted on the final filters under a stereoscope (Olympus SZX10), and their number and shape type (film, fragment, filament, foam) were visually recorded. Individual particle size (longest dimension in $\mathrm{mm}$ and area in $\mathrm{mm}^{2}$ ) was recorded with image-analysis software (Infinity Analyze). To minimize contamination, sample processing was conducted under a laminar flow bench. Fiberfree (Tyvek) lab coats were used. Airborne contamination was estimated by using blank filters at all stages of the analyses. MPs present in samples with features similar to those collected on the blanks were not taken into account.

\subsection{FT-IR Analysis}

For the characterization of the MP polymer type in river-water samples, an ATR-FTIR spectroscope (Agilent Cary 630) was used. Polymer identification was made possible using a combination of the instrument and inhouse libraries. Spectral range was $4000-650 \mathrm{~cm}^{-1}$ with a resolution of $4 \mathrm{~cm}^{-1}$ and $32 \mathrm{scans} \mathrm{sec}^{-1}$. The threshold for \% spectra similarity was set to $80 \%$, and integration time to $8 \mathrm{~s}$. For the characterization of MPs collected from the WWTPs, the FTIR Agilent Cary 630 instrument was equipped with a microspectroscopy accessory, Survey IRTM (Czitek). The use of this accessory enabled us to identify small particles and especially filaments. This accessory allows for the collection of spectra in transmission, reflection, and attenuated total reflection (ATR); in our case, reflection mode was used. Microscopy target opening was set to $80 \mu \mathrm{m}$. Analyses was performed at the IR region from 4000 to $650 \mathrm{~cm}^{-1}$. KBr detector was employed in FT-IR, background and sample scans were $160 \mathrm{sec}^{-1}$, the new background was collected on every sample, and the resolution was $8 \mathrm{~cm}^{-1}$.

\section{Results}

\subsection{Microplastics in Rivers}

In Kifissos River, the total number of counted MPs (including mesoplastics caught in the net) during high-flow conditions was 2171 particles; during low flow, it was 321 particles. In Pinios River, 200 and 182 MPs were counted in each of the two replicate samples collected on 11 June 2019. The resulting concentrations of MPs per water volume for Kifissos River were 27.7 and 8.11 items $\mathrm{m}^{-3}$, while concentrations in the two replicates of Pinios River were very close, equal to 1.95 and 1.77 items $\mathrm{m}^{3}$, respectively (Table 1 ).

Table 1. Microplastic (MP) concentrations in river waters and water fluxes during sampling.

\begin{tabular}{ccccc}
\hline River & Sampling Date & Sample & Water Flux & MPs \\
\hline \multirow{2}{*}{ Kifissos } & 6 December 2018 & K1 & $\mathbf{m}^{\mathbf{3}} \mathbf{s}^{-\mathbf{1}}$ & ${\text { Items } \mathbf{~ m}^{-\mathbf{3}}}^{*}$ \\
& 10 July 2019 & K2 & 0.29 & 27.73 \\
Pinios & 11 June 2019 & P073A & 0.054 & 8.11 \\
& & P073B & 0.9 & 1.95 \\
\hline
\end{tabular}

Figure 3a shows the percentage contribution of various shape types of MPs recorded in the samples. In the sample collected in Kifissos River in winter 2018 during high-flow conditions, films corresponded to $90 \%$ of the total number of MPs, and filaments and fragments to $6 \%$ and $4 \%$, respectively. The samples collected from both rivers during summer low-flow conditions had very similar composition. Once again, films appeared to be the dominant category, corresponding to $56-59 \%$, followed by filaments with $20-30 \%$ and 
fragments at $3-17 \%$. Foam particles were present in very low abundance, corresponding to $0.08-4 \%$ of the total number of particles. Pellets were not detected in our samples.

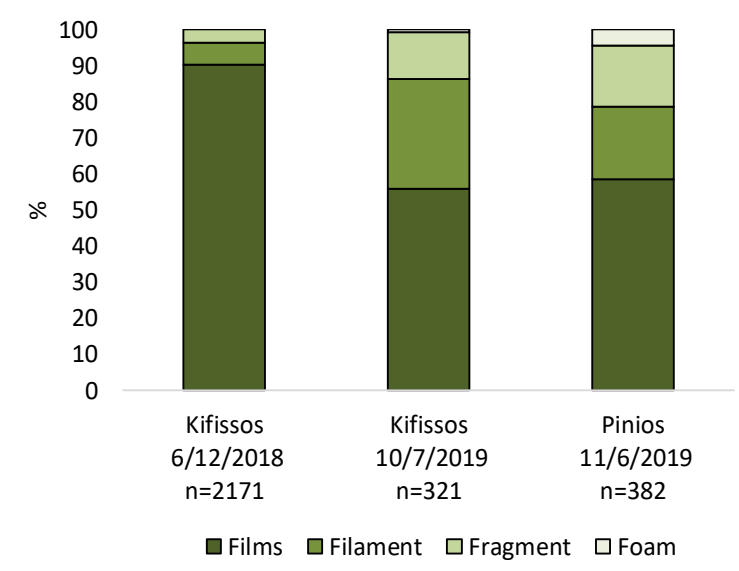

(a)

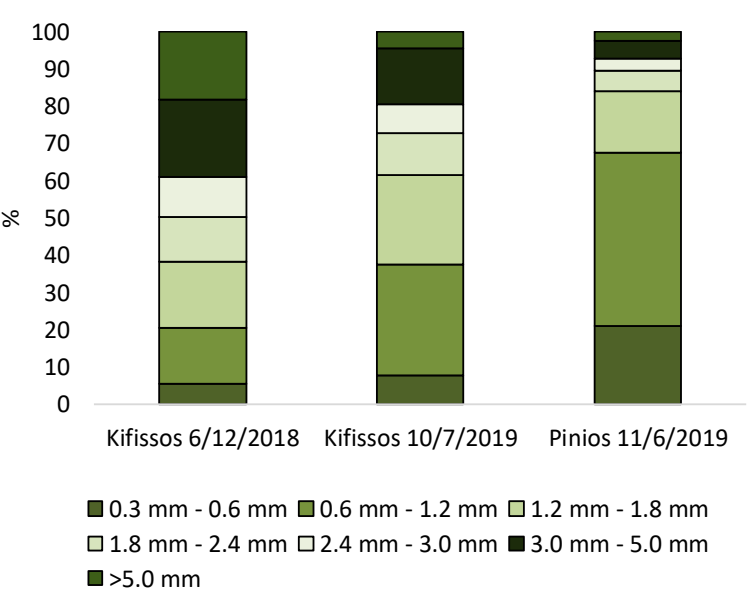

(b)

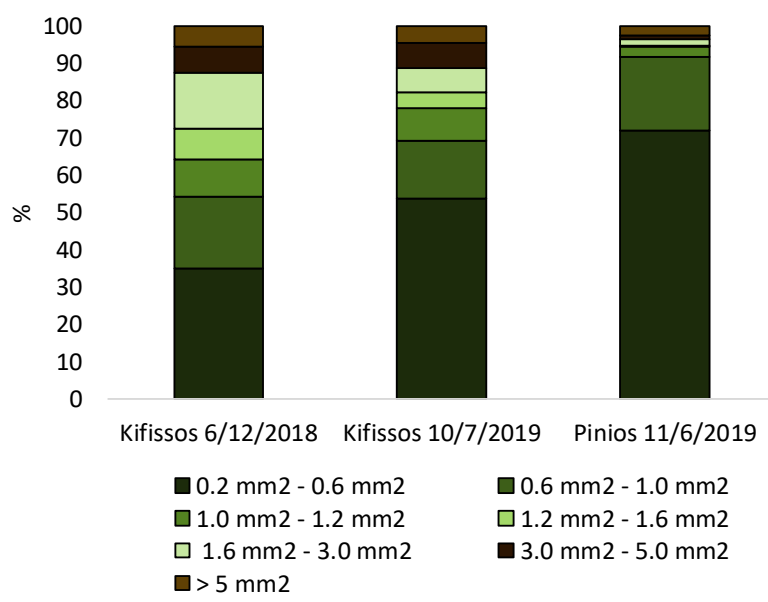

(c)

Figure 3. MP properties in river waters. Percentage contribution of (a) shape types, (b) sizes according to longest MP dimension ( $\mathrm{mm}$ ), and (c) sizes according to MP area $\left(\mathrm{mm}^{2}\right)$ excluding filaments. For Pinios River, distributions corresponded to the total number of MPs collected in the 2 replicates. Sizes of mesoplastic particles $(>5 \mathrm{~mm}$ ) caught in the net are also shown. 
We further determined the individual sizes of all MPs using image analysis presented in Figure 3b,c. Both samples collected in the urban Kifissos River were dominated by MPs with relatively large sizes (average length: $3.07 \pm 2.34 \mathrm{~mm}$ on 6 December 2018; $2.21 \pm 2.72 \mathrm{~mm}$ on 10 July 2019 ). About $\sim 60 \%$ of the particles had $<3.0 \mathrm{~mm}$ sizes during high-flow conditions, and $80 \%$ during low flow. On the other hand, in the two replicate samples of Pinios River, up to $93 \%$ of the particles corresponded to size bins $<3.0 \mathrm{~mm}$ $(84 \%<1.4 \mathrm{~mm})$ (average length: $1.59 \pm 3.31 \mathrm{~mm})$. Similarly, the percentage of particles (excluding filaments) with area $\leq 1 \mathrm{~mm}^{2}$ in Kifissos River was only $54 \%$ in winter, rising to $69 \%$ in summer; for the two replicate samples collected in Pinios River, this percentage reached 91\% (Figure 3c). The size analysis of the MPs described above shows that, in the urban Kifissos River, there is proliferation of relatively larger particles, including mesoplastics ( $>5 \mathrm{~mm}$ ), in contrast to Pinios River, were small particles were present.

Polymer identification using ATR-FTIR spectroscopy was carried out for $\sim 10 \%$ of the particles found in Kifissos River during high-flow conditions (i.e., 229 particles; Sample K1) and for all particles found in one of the replicate samples in Pinios River (i.e., 184 particles; Sample PO73A). Results for the two rivers are shown in Figure 4. There were contrasting differences between the two rivers. In the urban Kifissos River, there was a dominance of polyethylene (PE) particles (94\%) and a small percentage of polypropylene (PP) ones (6\%). In contrast, in Pinios River, with a considerably larger catchment area, about 9 different polymers were identified. In this case, polyethylene (PE) was also the most abundant (56\%), but the presence of polyvinyl acetate (PVAc) and polypropylene (PP) particles was also significant with $18 \%$ and $11 \%$, respectively. Less abundant polymer particles were of polystyrene (PS) $(6 \%)$, polyvinylchloride (PVC) (3\%), polyoxymethylene (POM) (3\%), and polyethylene terephthalate (PET), thermoplastic elastomers (TPE), and polyurethane (PU), with $1 \%$ each.

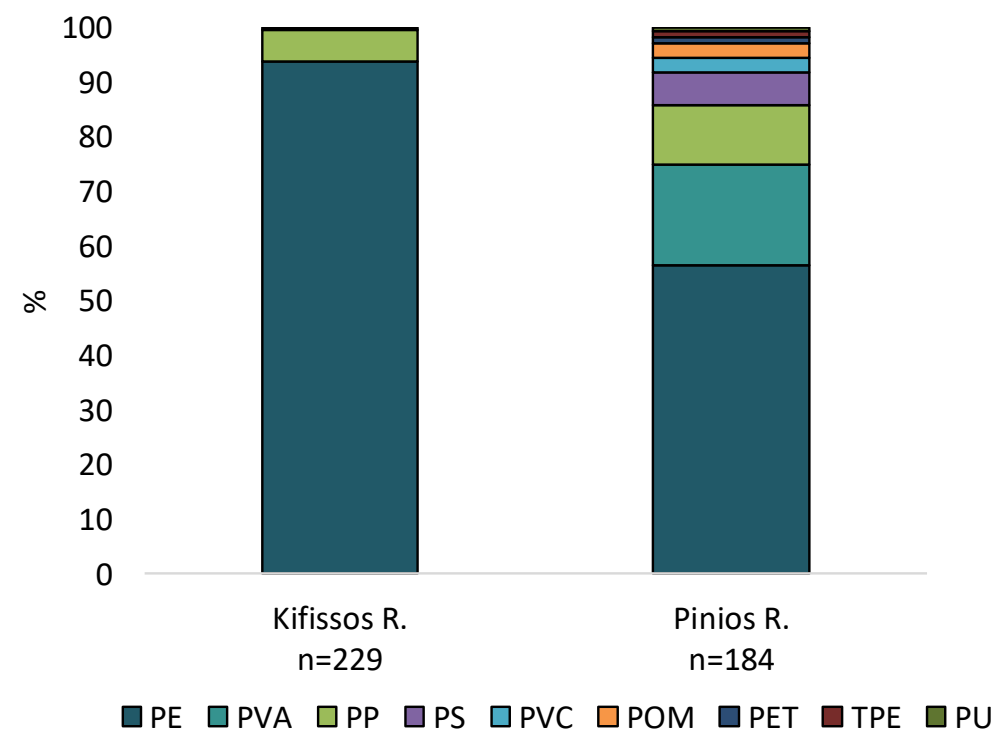

Figure 4. Polymeric composition of MPs in Kifissos and Pinios River waters.

\subsection{Microplastics in WWTPS}

MP concentrations in the WWTP samples are shown in Table 2. The samples of influents in both plants showed very similar concentrations of MPs, $\sim 40,000$ items $\mathrm{m}^{-3}$. In the effluent samples from secondary sedimentation and MBR, MP concentrations were lower by 2 and 4 orders of magnitude, 213 and 2.29 items $\mathrm{m}^{-3}$, respectively. These results are dependent on analytical capabilities regarding the lowest size detection; in our case, this was $100 \mu \mathrm{m}$. 
Table 2. MP concentrations in sewage influents and effluents. Average values of two sampling dates. Results of other works from the literature are included for comparison.

\begin{tabular}{|c|c|c|c|c|c|}
\hline & $\begin{array}{l}\text { Treatment } \\
\text { Technology }\end{array}$ & $\begin{array}{c}\text { Mesh Size } \\
(\mathrm{mm})\end{array}$ & 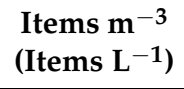 & 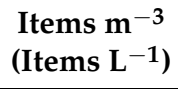 & Reference \\
\hline & & & Influents & Effluents & \\
\hline Greece & $\begin{array}{l}\text { Secondary } \\
\text { treatment }\end{array}$ & 0.100 & $\begin{array}{c}38,667 \\
(38)\end{array}$ & $\begin{array}{l}213^{*} \\
(0.4)\end{array}$ & Present work \\
\hline Greece & Pilot MBR & 0.100 & $\begin{array}{c}41,000 \\
(41)\end{array}$ & $\begin{array}{l}2.29 * * \\
(0.002)\end{array}$ & \\
\hline USA & $\begin{array}{l}\text { Secondary } \\
\text { treatment }\end{array}$ & 0.125 & - & $(0.14)^{* * *}$ & [39] \\
\hline USA & $\begin{array}{l}\text { Secondary } \\
\text { treatment }\end{array}$ & 0.125 & - & $(0.050)^{* * * *}$ & [40] \\
\hline Finland & $\begin{array}{l}\text { Secondary } \\
\text { treatment } \\
\text { Pilot MBR }\end{array}$ & 0.250 & (57) & $\begin{array}{l}(1.0) \\
(0.4)\end{array}$ & {$[41]$} \\
\hline
\end{tabular}

Since both plants operate within the greater Athens metropolitan area, and samples gave similar results in MP concentrations in the influents, we show combined data on MP properties in the influents for the two plants. Regarding the various types of MPs identified in the influents, filaments were dominant $(\sim 75 \%)$, followed by films and fragments (Figures 5 and 6a). Compositional differences between influent and effluent samples imply that the secondary treatment did not show any selective retention capability, with filaments holding $\sim 80 \%$ share, while the MBR treatment appeared to be more effective on filaments. In the MBR permeate, filaments and films held a more or less equal share ( $40 \%)$. As shown in Figure $6 \mathrm{~b}$, about $78 \%$ of MPs had lengths $\leq 1.2 \mathrm{~mm}$ in both influents and effluents, and low percentages of larger MPs were present in all types of sewage. For the smaller particles, however, results showed that the effectiveness of the secondary treatment progressively increased from the $0.1-0.4 \mathrm{~mm}$ to the $0.8-1.2 \mathrm{~mm}$ size range, while MBR seemed to be more or less equally effective for all size ranges. The detection of MPs in the MBR permeate with sizes larger than the membrane pore size is quite surprising and may be related to elongated particles (e.g., filaments) that may pass the membrane pore by their shortest dimension, which is in the order of the membrane pore opening. However, no sound conclusions can be drawn due to the limited number of analyzed samples in the present study.

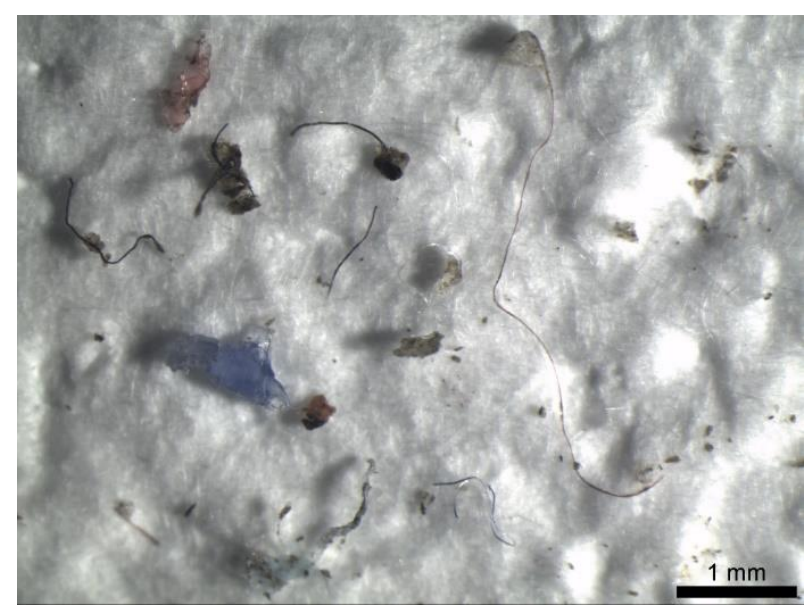

Figure 5. MP shape types of filaments, films, and fragments present in WWTP samples. 


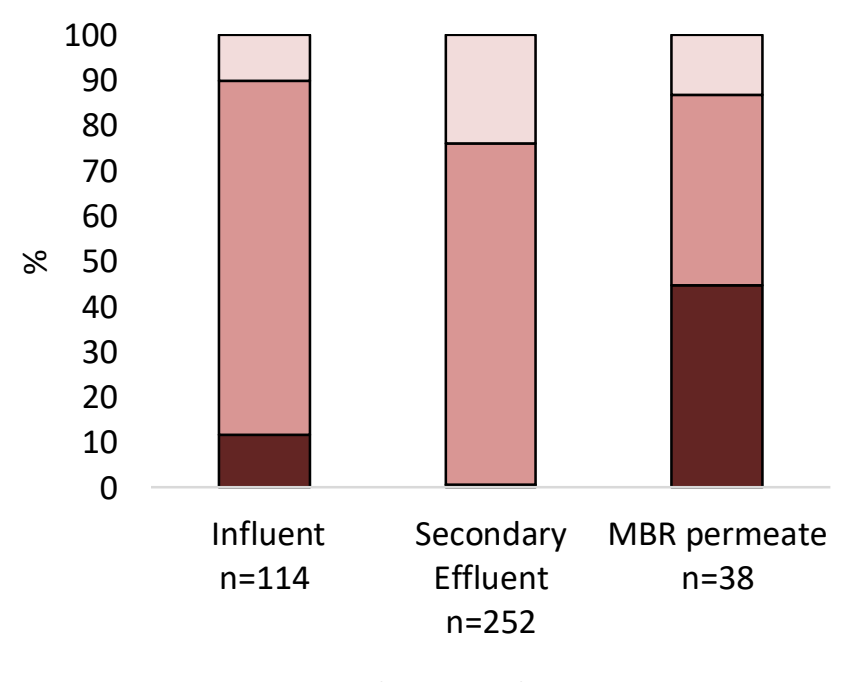

(a)

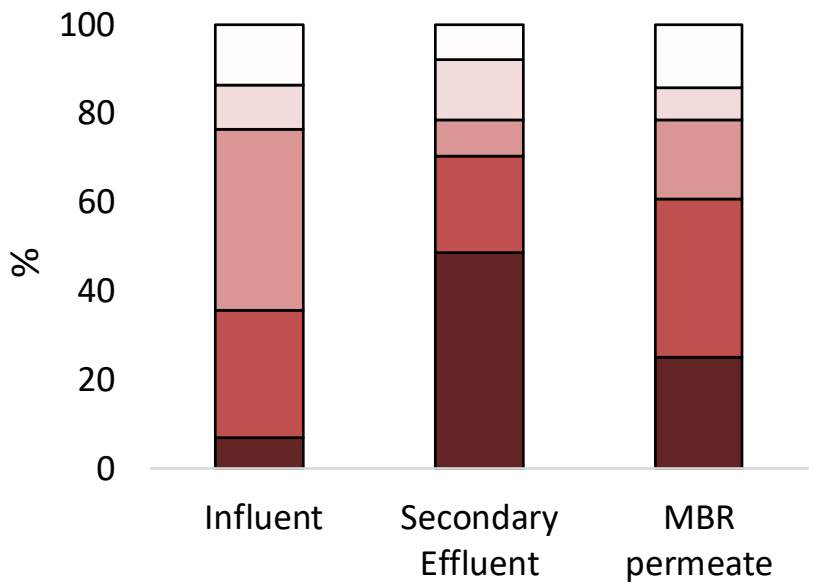

$\square 0.1-0.4 \mathrm{~mm} \quad \square 0.4-0.8 \mathrm{~mm} \quad \square 0.8-1.2 \mathrm{~mm}$

$\square 1.2-2.0 \mathrm{~mm} \quad \square>2.0 \mathrm{~mm}$

(b)

Figure 6. MP properties in wastewater. Percentage contribution of (a) shape types and (b) sizes according to longest MP dimension ( $\mathrm{mm})$.

In total, 444 particles were counted in the WWTP samples, and 44 particles including filaments were randomly selected and subjected to FTIR analysis using the microspectroscopy accessory. Six polymer types were identified. Figure 7a shows the relative contribution of these materials in the total number of MPs analyzed in influent and effluent samples. Found polymers were polyester and PET, acrylic, and polyamide PA-6 (nylon-6) (Figure $7 \mathrm{~b}$ ). These polymers, and PP and PE are used for textile manufacturing (synthetic clothes, sports clothing, carpets, etc.), and it is not surprising that they were present in household wastewaters. PE, PP, and PET can be found as fibers and in other forms, and they are the most commonly used polymers for plastic packaging. The only polymer not used in textiles and/or packaging is PU, which is related to various household products (e.g., kitchen or bathroom sponges). This description of polymer uses is reflected in their percentage contribution in our samples, where PP, PE, and PET held $80 \%$. 


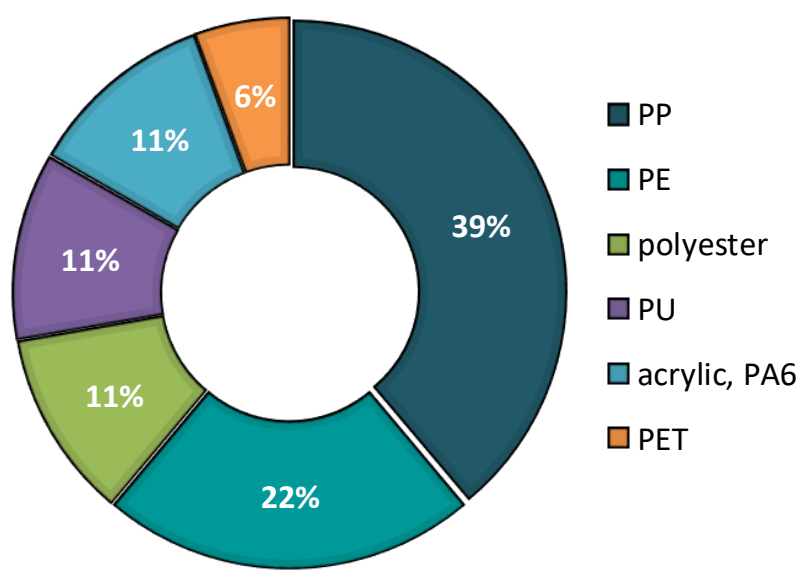

(a)

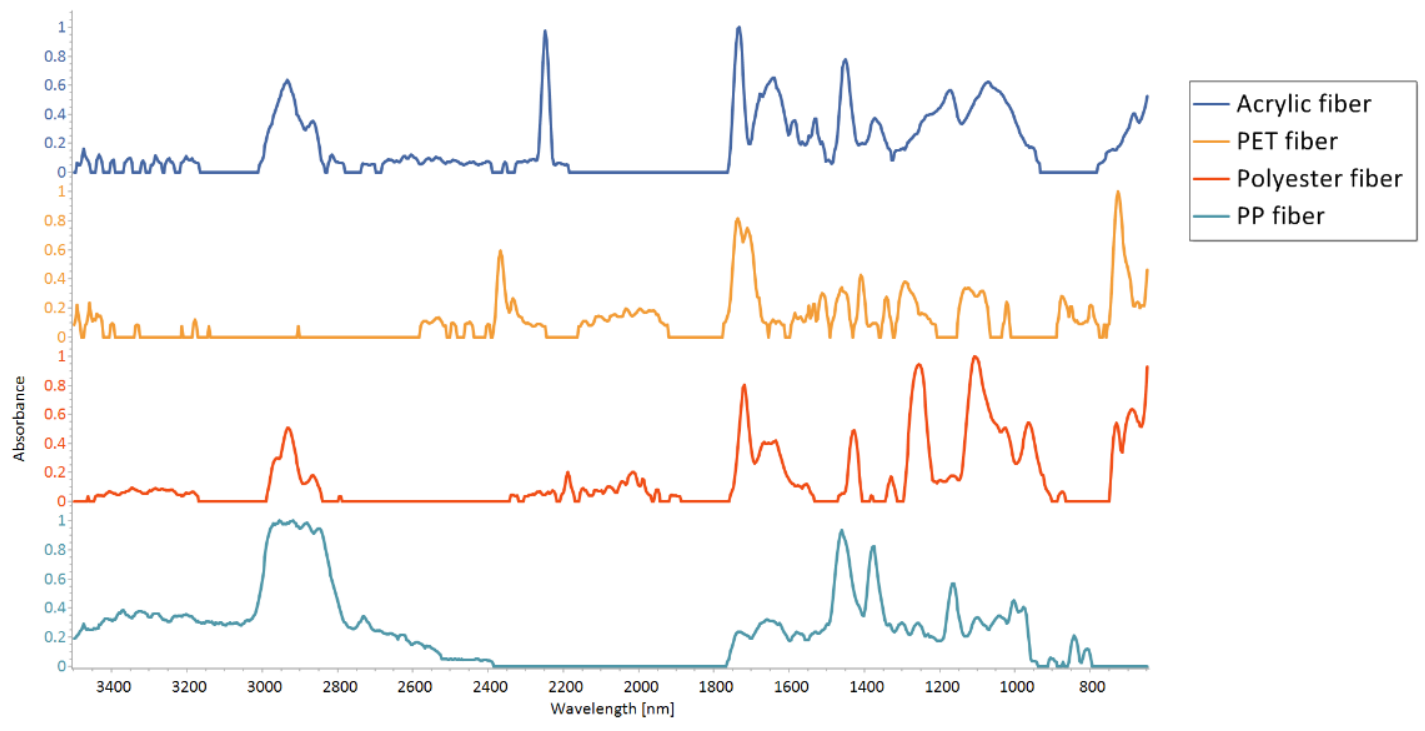

(b)

Figure 7. (a) Polymeric composition in subset of MPs $(n=44)$ analyzed in WWTP samples. (b) Representative FT-IR spectra of filaments or fibers found in WWPT samples.

\section{Discussion}

Rivers are highly dynamic systems because of the varying sizes and geological settings of their catchment areas, hydrological conditions, and the varying degree of human interventions (e.g., presence of dams, land uses, and urbanization). Consequently, environmental parameters in rivers exhibit high spatiotemporal variation. This is also the case for MPs in European and global fluvial systems [27,42-48]. The documented variability of MPs in rivers is further dependent on methodological differences among the various research groups, as can be seen in Table 3 for published data from European rivers. 
Table 3. MPs concentrations (items $\mathrm{m}^{-3} ; \mathrm{g} \mathrm{m}^{-3}$ ) in European River waters.

\begin{tabular}{|c|c|c|c|c|}
\hline $\begin{array}{l}\text { European } \\
\text { Rivers }\end{array}$ & Sampling Net & 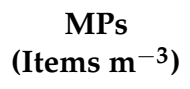 & $\begin{array}{c}\text { MPs } \\
\left(\mathrm{g} \mathrm{m}^{-3}\right)\end{array}$ & Source \\
\hline Ebro river & $\begin{array}{c}\text { Manta net } \\
(0.05 \mathrm{~mm}) \\
\mathrm{n}=3\end{array}$ & $3.5 \pm 1.4$ & & [27] \\
\hline Seine river & $\begin{array}{c}\text { Manta net } \\
(0.33 \mathrm{~mm}) \\
\mathrm{n}=5\end{array}$ & $0.28-0.47$ & & [42] \\
\hline Rhine river & $\begin{array}{c}\text { Manta net } \\
(0.33 \mathrm{~mm}) \\
\mathrm{n}=31\end{array}$ & $4 \pm 5$ & & [43] \\
\hline Rhone river & $\begin{array}{c}\text { Manta net } \\
(0.33 \mathrm{~mm}) \\
\mathrm{n}=13\end{array}$ & $12 \pm 18$ & 0.121 & [44] \\
\hline Tet river & $\begin{array}{c}\text { Manta net } \\
(0.33 \mathrm{~mm}) \\
\mathrm{n}=13\end{array}$ & $42 \pm 18$ & 0.831 & \\
\hline Swiss rivers & $\begin{array}{c}\text { Manta net } \\
(0.30 \mathrm{~mm}) \\
\mathrm{n}=24\end{array}$ & $7 \pm 0.20$ & & [45] \\
\hline Danube river & $\begin{array}{l}\text { Stationary drift } \\
\text { nets }(0.50 \mathrm{~mm})\end{array}$ & $0.316 \pm 4.66$ & $0.0048 \pm 0.024$ & [46] \\
\hline Pinios river & $\begin{array}{c}\text { Manta net } \\
(0.33 \mathrm{~mm}) \\
\mathrm{n}=2\end{array}$ & $1.86 \pm 0.12$ & - & Present study \\
\hline Kifissos river & $\begin{array}{c}\text { Manta net } \\
(0.33 \mathrm{~mm}) \\
\mathrm{n}=2\end{array}$ & $17.9 \pm 13.8$ & $0.0011 \pm 0.0011$ & \\
\hline
\end{tabular}

By comparing our results with those obtained with similar sampling net-mesh sizes $(0.30-0.33 \mathrm{~mm})$, it is obvious that MPs in the Greek rivers (Kifissos and Pinios) were found to be at least one order of magnitude higher than those reported for the Seine River [42], but fall within the range reported for the rivers Rhine [43], Rhone, Tet [44], and for several Swiss rivers [40]. In most works, filaments were found to be the dominant shape of MPs, in contrast to our work, where films were the most abundant shape. Local sources of MPs related to specific anthropogenic activities or attitudes are reflected in both the shape and polymer composition of the MP assortment in river water, as noted by other researchers [45,46]. In our case, the presence of films in both studied rivers reflects the fragmentation of larger litter, such as plastic bags or plastic sheets for various uses (agricultural uses, greenhouse sheets, industrial packaging). Indeed, at the site of our sampling at Kifissos River, the proliferation of plastic bags thrown along the riverbanks was obvious (Figure 2c). This is also reflected in the highest recorded percentage of PE (93\%). Moreover, high-flow conditions (sampling of 6 December 2018) in Kifissos River seemed to enhance the MP concentration, particularly the presence of films. Seasonal variability of MPs in river waters between wet and dry seasons was reported by Faure et al. (2015) for Swiss urban rivers [45] Vuachere (wet season: 680 items $\mathrm{m}^{-3}$; dry season: $4.4 \pm 1.3$ items $\mathrm{m}^{-3}$ ) and Venoge (wet season: $64 \pm 35$ items $\mathrm{m}^{-3}$; dry season: $6.5 \pm 5.3$ items $\mathrm{m}^{-3}$ ), and in other parts of the world $[47,48]$. The importance of flood events for the washout and transport of MPs in watersheds and coastal areas was highlighted for the Rhone and Tet rivers in France [44], for NW England catchments [49], and for the coastal waters of California, India, and the eastern Mediterranean Sea [50-55]. Variability was also observed in the size distribution of MPs collected in the two rivers, with particles in Kifissos River being larger (average length: $2.69 \pm 2.55 \mathrm{~mm}$; median: $1.85 \mathrm{~mm}$ ) than those in Pinios River (average length: $1.59 \pm 3.31 \mathrm{~mm}$; median: $0.89 \mathrm{~mm}$ ), indicating shorter residence time in the environment and a proximity to their original sources of littering for the Kifissos case. In this river, the identified MP polymers corresponded to those mostly used in consumption materials and 
packaging (PE, PVC, PP), and probably originate from the fragmentation of larger litter items, as noted for the polyethylene plastic bags. In Pinios River, on the other hand, apart from these three polymers, we were able to identify particles from other materials such as PVAc, PU, POM, and TPE. These are not used for packaging or household goods, but rather as adhesives, coatings, foam, and elastomers, and their presence in the environment is rather related to wearing out during usage than to fragmentation after being thrown away. Differences in both the size and the polymer type of MPs found in the two rivers probably reflect differences in drainage and catchment types. The urban Kifissos River has a relatively small catchment area and is subject to continuous local littering sources, so that, during high-flow conditions, accumulated material along its banks and adjacent areas is washed out as surface runoff. In contrast, Pinios River drains into a larger area, with urbanized, cultivated, and natural lands. These settings imply that MPs found in Pinios River originate from multiple sources and travelled long distances, while those found in Kifissos River reflect local sources. The two European directives on banning plastic bags (EU/720/2015) and single-use items (EU/904/2019) only very recently came into force in Greece (in 2019 and 2020, respectively), and they are expected to be an effective measure against plastic pollution in the country.

Apart from rivers, wastewater is also recognized to be an important MP source to aquatic environments. Despite the fact that most MPs are trapped in sludge during the treatment process, treated effluents from highly populated areas still deliver considerable amounts of MPs in adjacent aquatic or marine environments. In the case of the Athens metropolitan area, the concentration of MPs in the influents of two small plants, operating in the periphery of the city and discharging their effluents in the adjacent marine environment, was found to be surprisingly similar $\left(\sim 40,000\right.$ items $\mathrm{m}^{-3}$ for sizes $\left.\geq 0.1 \mathrm{~mm}\right)$. Reported MPs in raw wastewater largely varied (from $\sim 10 \times 10^{6}$ to 1000 items $\mathrm{m}^{-3}$ ), and this depends on different treatment conditions, diurnal and daily variations of the effluents, and on differences regarding the analytical detection limit of MP sizes [22,29,56]. Most studies used smaller mesh separation sieves or filters than ours, enabling the characterization and identification of particles down to $70-60$ or even $10 \mu \mathrm{m}[57,58]$. Three published works used mesh sizes of MP separation sieves that were comparable to ours, i.e., $0.125 \mathrm{~mm}[39,40]$ and $0.250 \mathrm{~mm}$ [41], and their results on sewage influents and effluents are given in Table 2 for comparison reasons. Consistent with other studies, filaments in both influents and effluents represented $\sim 73 \%$ of MPs $[30,37,40,41,57,59]$. They were made of polyester, PET, acrylic, PA6 (nylon-6) and PP. The latter had the highest share within filaments ( 35\%). All these materials are produced as yarns for textiles and fabrics, and are commonly reported in WWTP MP studies [30,41,59]. The most abundant fragment polymer was PE, as reported by others [41,59], while industrial pellets or microbeads were not detected at all in the samples. Overall, both treatment technologies (secondary treatment and MBR) show increased retention capacities ( $>99 \%$ ) for MPs $\geq 0.1 \mathrm{~mm}$, with the MBR treatment being more effective (99.99\%). The higher retention capacity of MBR treatment technologies was demonstrated by many relevant works $[31,60,61]$. Our results showed the presence of relatively large MPs, including fragments in the MBR permeate. While long filaments are expected to pass membrane pores, the presence of fragments in the MBR permeate was unexpected. Other studies reported similar findings, attributed to the occasional tearing of the membrane pores, leaks in seals of the unit, or to airborne contamination in open tanks where the permeate is collected $[21,31,41,59,61]$.

In many cases, WWTPs flow out into river systems, as is the case of Pinios River. Our sampling point there was downstream of the sewage discharges of the city of Larissa ( 150,000 inhabitants), yet MP properties did not reflect this point source (i.e., filaments and textile polymers were not dominant), but rather were indicative of multiple sources. This is related to various factors, such as the small size of the city, the retention of MPs within the river ecosystem, and the different buoyancy features of the various shapes, which are expected to affect concentrations and properties of the sampled mixture of MPs in Pinios' waters. At the large coastal urban centers, however, treated effluents are usually discharged 
either close to river mouths just before entering the marine environment or directly into it, as is the case of the city of Athens. The difference in MP concentrations by 1-2 orders of magnitude between river waters and sewage effluents from secondary treatment, as reported in the present study, highlights the significance of WWTPs as point sources of MP inputs, and the need for the application for advanced technologies such as the MBR, which showed increased retention capacity of MPs, at least for sizes $\geq 0.1 \mathrm{~mm}$. This agrees with previous works and models on MP transport from land to sea [62]; however, further research is needed in order to accurately determine the variability in MP concentrations and fluxes from these two pathways in the eastern Mediterranean Sea, and elucidate the role of rivers in MP retention.

The present work complements the gap in MP records for the two major pathways of MPs in the eastern Mediterranean basin, i.e., for river waters and treated sewage effluents. Results reflect a snapshot of MP amounts and properties in rivers and WWTPs in Greece, and are indicative of their relative contribution of MPs to Mediterranean waters. MP properties reflected local sources of plastic pollution, underling the usefulness of MP records in river systems towards targeting plastic-pollution mitigation measures. To that end, the inclusion of MP monitoring under the EU Water Framework Directive $(2000 / 60 / E C)$ is a useful tool. Wastewater clearly represents another major pathway of MPs into marine environments. Despite our limited data, the sewer mining unit operating with MBR technology was found to successfully retain a higher number of MPs. The rapidly changing hydrological regime of the Mediterranean basin with prolonged draught periods [63], in combination with the increase in urbanization rate (average rate of urban population $+1.9 \%$ per year) [64], will eventually lead to diminishing freshwater inputs and increasing urban-wastewater discharges to aquatic environments. In this context, the development and application of sewage-treatment technologies with a clear focus towards minimizing MP inputs in the receiving water bodies, is a pressing issue.

Author Contributions: Conceptualization, investigation, writing, and editing, C.Z.; investigation, formal analysis, and review, A.A.; investigation, formal analysis, and review, A.K.; investigation and writing review, N.K.; review and resources E.L.; review and funding acquisition, E.D. All authors have read and agreed to the published version of the manuscript.

Funding: This research was funded by (i) the National Monitoring Program for the Implementation of the WFD in Greece (MIS 5001676, Ministry for the Environment and Energy) and (ii) CLAIM Project: H2020-BG-2016-2017 (grant number 774,586), “Cleaning Litter by developing and Applying Innovative Methods in European seas".

Institutional Review Board Statement: Not applicable.

Informed Consent Statement: Not applicable.

Data Availability Statement: Data are contained within the article.

Conflicts of Interest: The authors declare no conflict of interest. The funders had no role in the design of the study; in the collection, analyses, or interpretation of data; in the writing of the manuscript, or in the decision to publish the results.

\section{References}

1. Bergmann, M.; Gutow, L.; Klages, M. (Eds.) Marine Anthropogenic Litter; Springer Open: Berlin/Heidelberg, Germany, 2015. [CrossRef]

2. Thompson, R.; Olsen, Y.; Mitchell, R.; Davis, A.; Rowland, S.; John, A.; McGonigle, D.; Russell, A. Lost at Sea: Where Is All the Plastic? Science 2004, 304, 838. [CrossRef]

3. Barnes, D.; Galgani, F.; Thompson, R.; Barlaz, M. Plastic accumulation and fragmentation. Philos. Trans. R. Soc. B Biol. Sci. 2009, 364, 1985-1998. [CrossRef]

4. Worm, B.; Lotze, H.K.; Jubinville, I.; Wilcox, C.; Jambeck, J. Plastic as a Persistent Marine Pollutant. Annu. Rev. Environ. Resour. 2017, 42, 1-26. [CrossRef]

5. GESAMP. Sources, Fate and Effects of Microplastics in the Marine Environment: Part Two of a Global Assessment; Kershaw, P.J., Rochman, C.M., Eds.; (IMO/FAO/UNESCO-IOC/UNIDO/WMO/IAEA/UN/UNEP/UNDP Joint Group of Experts on the Scientific Aspects of Marine Environmental Protection); GESAMP: London, UK, 2016; p. 220. 
6. $\quad$ Eriksen, M.; Lebreton, L.C.M.; Carson, H.S.; Thiel, M.; Moore, C.J.; Borerro, J.C.; Galgani, F.; Ryan, P.G.; Reisser, J. Plastic Pollution in the World's Oceans: More than 5 Trillion Plastic Pieces Weighing over 250,000 Tons Afloat at Sea. PLoS ONE 2014, 9, e111913. [CrossRef] [PubMed]

7. van Sebille, E.; Wilcox, C.; Lebreton, L.; Maximenko, N.; Hardesty, B.D.; van Franeker, J.A.; Eriksen, M.; Siegel, D.; Galgani, F.; Law, K.L. A global inventory of small floating plastic debris. Environ. Res. Lett. 2015, 10, 124006. [CrossRef]

8. Koelmans, A.A.; Kooi, M.; Law, K.L.; van Sebille, E. All is not lost: Deriving a top- down mass budget of plastic at sea. Environ. Res. Lett. 2017, 12, 1-9. [CrossRef]

9. Teuten, E.L.; Saquing, J.M.; Knappe, D.R.U.; Barlaz, M.A.; Jonsson, S.; BjÃrn, A.; Rowland, S.J.; Thompson, R.C.; Galloway, T.S.; Yamashita, R.; et al. Transport and release of chemicals from plastics to the environment and to wildlife. Philos. Trans. R. Soc. B Biol. Sci. 2009, 364, 2027-2045. [CrossRef] [PubMed]

10. Karapanagioti, H.K.; Endo, S.; Ogata, Y.; Takada, H. Diffuse pollution by persistent organic pollutants as measured in plastic pellets sampled from various beaches in Greece. Mar. Pollut. Bull. 2011, 62, 312-317. [CrossRef] [PubMed]

11. Koelmans, A.A.; Bakir, A.; Burton, G.A.; Janssen, C.R. Microplastic as a vector for chemicals in the aquatic environment: Critical review and model-supported reinterpretation of empirical studies. Environ. Sci. Technol. 2016, 50, 3315-3326. [CrossRef]

12. Digka, N.; Tsangaris, C.; Torre, M.; Anastasopoulou, A.; Zeri, C. Microplastics in mussels and fish from the Northern Ionian Sea. Mar. Pollut. Bull. 2018, 135, 30-40. [CrossRef]

13. Tutman, P.; Kapiris, K.; Kirinčić, M.; Pallaoro, A. Floating marine litter as a raft for drifting voyages for Planes minutus (Crustacea: Decapoda: Grapsidae) and Liocarcinus navigator (Crustacea: Decapoda: Polybiidae). Mar. Pollut. Bull. 2017, 120, $217-221$. [CrossRef]

14. Rech, S.; Pichs, Y.J.B.; Garcia-Vazquez, E. Anthropogenic marine litter composition in coastal areas may be a predictor of potentially invasive rafting fauna. PLOS ONE 2018, 13, e0191859. [CrossRef] [PubMed]

15. Romera-Castillo, C.; Pinto, M.; Langer, T.M.; Álvarez-Salgado, X.A.; Herndl, G.J. Dissolved organic carbon leaching from plastics stimulates microbial activity in the ocean. Nat. Commun. 2018, 9, 1430. [CrossRef] [PubMed]

16. Galgani, L.; Engel, A.; Rossi, C.; Donati, A.; Loiselle, S.A. Polystyrene microplastics increase microbial release of marine Chromophoric Dissolved Organic Matter in microcosm experiments. Sci. Rep. 2018, 8, 14635. [CrossRef]

17. Galgani, L.; Tsapakis, M.; Pitta, P.; Tsiola, A.; Tzempelikou, E.; Kalantzi, I.; Esposito, C.; Loiselle, A.; Tsotskou, A.; Zivanovic, S.; et al. Microplastics increase the marine production of particulate forms of organic matter. Environ. Res. Lett. 2020, $14,124085$. [CrossRef]

18. Lebreton, L.C.M.; van der Zwet, J.; Damsteeg, J.-W.; Slat, B.; Andrady, A.; Reisser, J. River plastic emissions to the world's oceans Nat. Commun. 2017, 8, 15611. [CrossRef]

19. Schmidt, C.; Krauth, T.; Wagner, S. Export of Plastic Debris by Rivers into the Sea. Environ. Sci. Technol. 2017, 51, 12246-12253. [CrossRef]

20. Meijer, L.J.J.; van Emmerik, T.; van der Ent, R.; Schmidt, C.; Lebreton, L. Over 1000 rivers accountable for $80 \%$ of global riverine plastic emissions into the ocean. EarthArXiv 2019. [CrossRef]

21. Michielssen, M.R.; Michielssen, E.R.; Ni, J.; Duhaime, M.B. Fate of microplastics and other small anthropogenic litter (SAL) in wastewater treatment plants depends on unit processes employed. Environ. Sci. Water Res. Technol. 2016, 2, 1064. [CrossRef]

22. Gatidou, G.; Arvaniti, O.S.; Stasinakis, A.S. Review on the occurrence and fate of microplastics in Sewage Treatment Plants. J. Hazard. Mater. 2019, 367, 504-512. [CrossRef] [PubMed]

23. Cózar, A.; Sanz-Martín, M.; Martí, E.; González-Gordillo, J.I.; Ubeda, B.; Gálvez, J.Á.; Irigoien, X.; Duarte, C.M. Plastic accumulation in the Mediterranean Sea. PLoS ONE 2015, 10, e0121762. [CrossRef]

24. Suaria, G.; Avio, C.G.; Mineo, A.; Lattin, G.L.; Magaldi, M.G.; Belmonte, G.; Moore, C.J.; Regoli, F.; Aliani, S. The Mediterranean plastic soup: Synthetic polymers in Mediterranean surface waters. Sci. Rep. 2016, 6, 37551. [CrossRef] [PubMed]

25. Zeri, C.; Adamopoulou, A.; Varezić, D.B.; Fortibuoni, T.; Viršek, M.K.; Kržan, A.; Mandic, M.; Mazziotti, C.; Palatinus, A.; Peterlin, M.; et al. Floating plastics in Adriatic waters (Mediterranean Sea): From the macro- to the micro- scale. Mar. Pollut. Bull. 2018, 136, 341-350. [CrossRef]

26. Guerranti, C.; Cannas, S.; Scopetani, C.; Fastelli, P.; Cincinelli, A.; Renzi, M. Plastic litter in aquatic environments of Maremma Regional Park (Tyrrhenian Sea, Italy): Contribution by the Ombrone river and levels in marine sediments. Mar. Pollut. Bull. 2017, 117, 366-370. [CrossRef] [PubMed]

27. Simon-Sánchez, L.; Grelaud, M.; Garcia-Orellana, J.; Ziveri, P. River Deltas as hotspots of microplastic accumulation: The case study of the Ebro River (NW Mediterranean). Sci. Total Environ. 2019, 687, 1186-1196. [CrossRef]

28. Magni, S.; Binelli, A.; Pittura, L.; Avio, C.G.; Della Torre, C.; Parenti, C.C.; Gorbi, S.; Regoli, F. The fate of microplastics in an Italian Wastewater Treatment Plant. Sci. Total Environ. 2019, 652, 602-610. [CrossRef] [PubMed]

29. Akarsu, C.; Kumbur, H.; Gökdağ, K.; Kideyş, A.E.; Sanchez-Vidal, A. Microplastics composition and load from three wastewater treatment plants discharging into Mersin Bay, north eastern Mediterranean Sea. Mar. Pollut. Bull. 2020, 150, 110776. [CrossRef]

30. Ben-David, E.A.; Habibi, M.; Haddad, E.; Hasanin, M.; Angel, D.L.; Booth, A.M.; Sabbah, I. Microplastic distributions in a domestic wastewater treatment plant: Removal efficiency, seasonal variation and influence of sampling technique. Sci. Total Environ. 2021, 752, 141880. [CrossRef] [PubMed] 
31. Pittura, L.; Foglia, A.; Akyol, Ç.; Cipolletta, G.; Benedetti, M.; Regoli, F.; Eusebi, A.L.; Sabbatini, S.; Tseng, L.Y.; Katsou, E.; et al. Microplastics in real wastewater treatment schemes: Comparative assessment and relevant inhibition effects on anaerobic processes. Chemosphere 2021, 262, 128415. [CrossRef]

32. Lindström, G.; Pers, C.P.; Rosberg, R.; Strömqvist, J.; Arheimer, B. Development and test of the HYPE (Hydrological Predictions for the Environment) model-A water quality model for different spatial scales. Hydrol. Res. 2010, 41, 295-319. [CrossRef]

33. Mazi, K.; Koussis, A.D. The 8 July 2002 Storm Over Athens: Analysis of the Kifissos River/Canal Overflows; Advances in Geosciences; European Geosciences Union: Munich, Germany, 2006; Volume 7, pp. 301-306.

34. Partsinevelou, A.-S.; Evrenoglou, L. Heavy metal contamination in surface water and impacts in public health. The case of Kifissos River, Athens. Greece Int. J. Energy Environ. 2016, 10, 213-216.

35. Panagiotopoulos, I.; Kapsimalis, V.; Hatzianestis, I.; Kanellopoulos, T.D.; Kyriakidou, C. Environmental status of the metropolitan river (Kifissos) of Athens, Greece. Environ. Earth Sci. 2010, 61, 983-993. [CrossRef]

36. Bellos, D.; Sawidis, T. Chemical pollution monitoring of the river Pinios (Thessalia-Greece). J. Environ. Manag. 2005, 76, 282-292. [CrossRef]

37. Talvitie, J.; Heinonen, M.; Pääkkönen, J.-P.; Vahtera, E.; Mikola, A.; Setälä, O.; Vahala, R. Do wastewater treatment plants act as a potential point source of microplastics? Preliminary study in the coastal Gulf of Finland, Baltic Sea. Water Sci. Technol. 2015, 72, 1495-1504. [CrossRef] [PubMed]

38. GESAMP. Guidelines or the Monitoring and Assessment of Plastic Litter and Microplastics in the Ocean; Kershaw, P.J., Turra, A., Galgani, F., Eds.; (IMO/FAO/UNESCO-IOC/UNIDO/WMO/IAEA/UN/UNEP/UNDP/ISA Joint Group of Experts on the Scientific Aspects of Marine Environmental Protection); GESAMP: London, UK, 2019; p. 130.

39. Dyachenko, A.; Mitchell, J.; Arsem, N. Extraction and identification of microplastic particles from secondary wastewater treatment plant (WWTP) effluent. Anal. Methods 2017, 9, 1412-1418. [CrossRef]

40. Mason, S.A.; Garneau, D.; Sutton, R.; Chu, Y.; Ehmann, K.; Barnes, J.; Fink, P.; Papazissimos, D.; Rogers, D.L. Microplastic pollution is widely detected in US municipal wastewater treatment plant effluent. Environ. Pollut. 2016, 218, 1045-1054. [CrossRef] [PubMed]

41. Lares, M.; Ncibi, M.C.; Markus, S.; Mika, S. Occurrence, identification and removal of microplastic particles and fibers in conventional activated sludge process and advanced MBR technology. Water Res. 2018, 133, 236-246. [CrossRef]

42. Dris, R.; Gasperi, J.; Rocher, V.; Saad, M.; Renault, N.; Tassin, B. Microplastic contamination in an urban area: A case study in greater Paris. Environ. Chem. 2015, 12, 592. [CrossRef]

43. Mani, T.; Hauk, A.; Walter, U.; Burkhardt-Holm, P. Microplastics profile along the Rhine river. Sci. Rep. 2015, 5, 17988. [CrossRef]

44. Constant, M.; Ludwig, W.; Kerhervé, P.; Sola, J.; Charrière, B.; Sanchez-Vidal, A.; Canals, M.; Heussner, S. Microplastic fluxes in a large and a small Mediterranean river catchments: The Têt and the Rhône, Northwestern Mediterranean Sea. Sci. Total Environ. 2020, 716, 136984. [CrossRef]

45. Faure, F.; Demars, C.; Wieser, O.; Kunz, M.; de Alencastro, L.F. Plastic pollution in Swiss surface waters: Nature and concentrations, interaction with pollutants. Environ. Chem. 2015, 12, 582-591. [CrossRef]

46. Lechner, A.; Keckeis, H.; Lumesberger-Lois, F.; Zens, B.; Krusch, R.; Tritthart, M.; Glas, M.; Schludermann, E. The Danube so colourful: A potpourri of plastic litter outnumbers fish larvae in Europe's second largest river. Environ. Pollut. 2014, 188, 177-181. [CrossRef]

47. Zhao, S.Y.; Zhu, L.X.; Li, D.J. Microplastic in three urban estuaries, China. Environ. Pollut. 2015, 206, 597-604. [CrossRef]

48. Kapp, K.J.; Yeatman, E. Microplastic hotspots in the Snake and lower Columbia rivers: A journey from the greater Yellowstone ecosystem to the Pacific ocean. Environ. Pollut. 2018, 241, 1082-1090. [CrossRef] [PubMed]

49. Dikareva, N.; Simon, K.S. Microplastic pollution in streams spanning an urbanisation gradient. Environ. Pollut. 2019, 250, 292-299. [CrossRef] [PubMed]

50. Mai, L.; You, S.-N.; He, H.; Bao, L.-J.; Liu, L.-Y.; Zeng, E.Y. Riverine Microplastic Pollution in the Pearl River Delta, China: Are Modeled Estimates Accurate? Environ. Sci. Technol. 2019, 53, 11810-11817. [CrossRef] [PubMed]

51. Lima, A.R.A.; Costa, M.F.; Barletta, M. Distribution patterns of microplastics within the plankton of a tropical estuary. Environ. Res. 2014, 132, 146-155. [CrossRef] [PubMed]

52. Hurley, R.; Woodward, J.; Rothwell, J.J. Microplastic contamination of riverbeds significantly reduced by catchment-wide flooding. Nat. Geosci. 2018, 11, 251-257. [CrossRef]

53. Moore, C.J.; Moore, S.L.; Weisberg, S.B.; Lattin, G.L.; Zellers, A.F. A comparison of neustonic plastic and zooplankton abundance in southern California's coastal waters. Mar. Pollut. Bull. 2002, 44, 1035-1038. [CrossRef]

54. Veerasingam, S.; Mugilarasan, M.; Venkatachalapathy, R.; Vethamony, P. Influence of 2015 flood on the distribution and occurrence of microplastic pellets along the Chennai coast, India. Mar. Pollut. Bull. 2016, 109, 196-204. [CrossRef]

55. Gündoğdu, S.; Çevik, C. Micro- and mesoplastics in Northeast Levantine coast of Turkey: The preliminary results from surface samples. Mar. Pollut. Bull. 2017, 118, 341-347. [CrossRef]

56. Sun, J.; Dai, X.; Wang, Q.; van Loosdrecht, M.C.M.; Ni, B.J. Microplastics in wastewater treatment plants: Detection, occurrence and removal. Water Res. 2019, 152, 21-37. [CrossRef]

57. Leslie, H.A.; Brandsma, S.H.; van Velzen, M.J.M.; Vethaak, A.D. Microplastics en route: Field measurements in the Dutch river delta and Amsterdam canals, wastewater treatment plants, North Sea sediments and biota. Environ. Int. 2017, 101, 133-142. [CrossRef] 
58. Mintenig, S.M.; Int-Veen, I.; Loder, M.G.J.; Primpke, S.; Gerdts, G. Identification of microplastic in effluents of waste water treatment plants using focal plane array-based micro-Fourier-transform infrared imaging. Water Res. 2017, 108, 365-372. [CrossRef]

59. Ziajahromi, S.; Neale, P.A.; Rintoul, L.; Leusch, F.D.L. Wastewater treatment plants as a pathway for microplastics: Development of a new approach to sample wastewater-based microplastics. Water Res. 2017, 112, 93-99. [CrossRef]

60. Hu, Y.; Gong, M.; Wang, J.; Bassi, A. Current research trends on microplastic pollution from wastewater systems: A critical review. Rev. Environ. Sci. Biotechnol. 2019, 18, 207-230. [CrossRef]

61. Talvitie, J.; Mikola, A.; Koistinen, A.; Setala, O. Solutions to microplastic pollution and removal of microplastics from wastewater effluent with advanced wastewater treatment technologies. Water Res. 2017, 123, 401-407. [CrossRef]

62. Siegfried, M.; Koelmans, A.A.; Besseling, E.; Kroeze, C. Export of microplastics from land to sea. A modelling approach. Water Res. 2017, 127, 249-257. [CrossRef] [PubMed]

63. Tuel, A.; Eltahir, E.A.B. Why is the Mediterranean a climate change hot-spot? J. Clim. 2020, 33, 5829-5843. [CrossRef]

64. UNEP/MAP. Mediterranean Quality Status Report Quality Status Report for the Mediterranean-MED QSR 2017; UNEPMAP: Nairobi, Kenya, 2017. 